\title{
Use of Demolished Material in Concrete
}

\author{
Mr. Manish S. Deshmukh
}

\begin{abstract}
Now days, demolition of older building structures to clear a path for new and current structures are normal highlights in urban zones because of fast and growing urbanization. Be that as it may, almost no obliterated cement is reused or reused. The severe ecological laws and absence of dumping locales in urban zones on one hand are making the removal of destruction squanders dangerous while then again the quarrying of crude materials is getting troublesome. In this paper we are investigating the replacement effect of cement, aggregate (Fine/Coarse) based on various size of demolished materials strength and working ability of concrete. In this study is to analyze mix concrete with M25 grade was designed based on IS code 10262-2009. So that one time is changing the material of concrete. We have measured the compressive strength of concrete at 7 to 28 days with $20 \%$ fine aggregate was used and compare with demolished waste at 28 days. The compressive quality of reused solid made utilizing 30\% of demolished squander coarse aggregate is practically same as referred concrete. The outcomes show that still higher substitution of the constituent materials is conceivable absent really any trading off the 28 days quality and functionality of concrete.
\end{abstract}

Index Terms - Concrete, compressive strength, recycled concrete, cement

\section{INTRODUCTION}

Development of materials is progressively decided by their Environmental attributes. Recycling is the important factor in concrete technology because it secures common assets and to eliminates requirement for removal by utilizing the promptly accessible concrete such as fine and Coarse aggregate for new concrete. Reusing of concrete and cement is moderately basic procedure. It includes evacuating, squashing, breaking of existing cement of material with a predefined size and quality. The devastating attributes of solidified cement as like as the normal stone and are not altogether influenced by the evaluation or nature of the first concrete. Reused of aggregate in concrete is designed from everything except the most unfortunate quality unique cement can be relied upon to breeze through similar assessments expected of regular aggregate.

The crushing characteristics of hardened concrete are similar to those of natural rock and are not significantly affected by the grade or quality of the original concrete. Recycled concrete aggregates produced from all but the

Manuscript revised May 23, 2020 and published on June 10, 2020 Mr. Manish S. Deshmukh, Assistant Professor at P. R. Pote College of Engineering, Amravati poorest quality original concrete can be expected to pass the same tests required of conventional aggregates. This Investigation is utilization of reused fine and coarse aggregate for the most part centered on the coarse portion and disregarded the fine portion. The fundamentally on the grounds that the extraordinary porosity of fine reused materials prompts decreases the presentation of any composites concrete. The most significant attributes of solidified mortar for divider covers such as mechanical quality, water porousness, cement quality and protection from enduring, furthermore, those of new mortar are working capacity, and water retentively.

\section{RELATED WORK}

Ferrari et. al. [1] investigation of this paper we understand that A strategy for reusing recovered cement is uncovered, involving the expansion of 1) streak set quickening agents 2) super-permeable polymers to disconnected remaining new disconnected cement and mixing this blend until granular materials are framed in blend plan M25 blend structure.

Preeti Saini et. al. [2], anaylsis of this paper get that gathering the pre-owned cement and separating it, reused solid totals produced, The utilization of reused solid total as course total in solid blend has been started, to utilize the waste materials. Whenever reused total over $60 \%$ than its effect on solid properties decreased $25-30 \%$.

P. Saravanakumar et. al. [3] examination data that compressive and elasticity of admixed RAC has been seen as low quality of NAC. 90 days of quality increases and improvement in solid over $20 \%$ concrete substitution GGBFS without GGBFS. 41\% GGBFS invigorates higher with half RA. Chloride particle infiltration test was watched higher substitution (half) concrete degree of $12 \%$ GGBFS for 25 to $100 \%$ RA.

Jitender Sharma et. al. [4] examination of this paper gives essential thought regarding presentation and creation of reused solid totals from crushed waste, lessen utilization of normal totals and decrease cost of solid, general investigation of reused total. When to W/C proportion utilized in RA blend is decreased, rigidity and modules of versatility are more; High water retention and porosity. $100 \%$ substitution of NA by RCA in solid blend may impact on chloride particles opposition, if legitimate plan isn't embraced.

Manish Kumar Singh et. al. [5] examination gives the thought regarding the squashed development and crushed solid squanders is isolated by sieving to acquire needed area of total, a few tests are led to decide the total properties before reusing it into new concrete. Development and Demolished waste is utilized as the coarse total in new concrete. Utilization of the waste total in the new concrete as the reused 
solid total diminishes the natural contamination just as giving a monetary incentive to the waste material.

\section{Material ANd Methodology}

The current work is an endeavor to investigate the chance of utilizing reusing the losses of various sizes acquired from annihilated cement for future employments. To achieve an extensive exploratory program was intended to survey the chance of fractional substitution of ordinary solid materials by a less expensive and effectively accessible substitute for example destruction squander. Demolish cement are squashed and sieve based on IS strainer to isolate the coarse and fine aggregate. The IS sifters utilized such as $80 \mathrm{~mm}, 40$ $\mathrm{mm}, 20 \mathrm{~mm}, 10 \mathrm{~mm}, 4.75 \mathrm{~mm}, 2.36 \mathrm{~mm}, 1.18 \mathrm{~mm}, 600 \mu$, $300 \mu \& 150 \mu$. The parts passing $20 \mathrm{~mm}$ and held on 4.75 $\mathrm{mm}$ IS sifter are utilized the coarse aggregate is replaced. The significant properties of various size parts and got using destruction squander concrete are Coarse Aggregate Fineness Modulus are $7.10 \&$ Specific gravity are 2.54.

Cement

Table 1: Cement Property

\begin{tabular}{|l|c|}
\hline \multicolumn{1}{|c|}{ Characteristics } & Values \\
\hline Specific Gravity & 03.15 \\
\hline Normal Consistency & $031 \%$ \\
\hline Initial Setting Time & $032 \mathrm{~min}$ \\
\hline Final Setting Time & $0205 \mathrm{~min}$ \\
\hline
\end{tabular}

\section{Fine Aggregate}

Table 2: Fine Aggregate Property

\begin{tabular}{|c|c|}
\hline Characteristics & Values \\
\hline Zone & II \\
\hline Specific Gravity & 2.64 \\
\hline Density & $14 \mathrm{KN} / \mathrm{m}^{3}$ \\
\hline
\end{tabular}

\section{Coarse Aggregate}

Table 3: Coarse Aggregate Property

\begin{tabular}{|c|c|}
\hline Characteristics & Values \\
\hline Nominal Size & $10 \mathrm{~mm}$ \\
\hline Specific Gravity & 2.84 \\
\hline Density & $1625.83 \mathrm{Kg} / \mathrm{m} 3$ \\
\hline
\end{tabular}

Water: Water and cement ratio are 0.40 for M25

\section{Mix Proportions}

Table 4: Mix proportions details

\begin{tabular}{|c|c|}
\hline Mix & Mix details \\
\hline A0 & Normal Concrete $(100 \%)$ \\
\hline A1 & $20 \%$ RCA $+80 \%$ NCA \\
\hline
\end{tabular}

\begin{tabular}{|l|l|}
\hline A3 & $40 \% \mathrm{RCA}+60 \% \mathrm{NCA}$ \\
\hline A4 & $60 \% \mathrm{RCA}+40 \% \mathrm{NCA}$ \\
\hline A5 & $80 \% \mathrm{RCA}+20 \% \mathrm{NCA}$ \\
\hline A6 & $100 \% \mathrm{RCA}+0 \% \mathrm{NCA}$ \\
\hline
\end{tabular}

\section{Experimental Investigation}

Testing compressive strength

Solid 3D shapes of sizes $150 \mathrm{~mm} \times 150 \mathrm{~mm} \times 150 \mathrm{~mm}$ of concrete are tried for pounding quality. Compressive quality relies upon heaps factor, for example, w/c proportion; concrete quality, greatness of solid material and greatness control during production of cement. These 3D shapes are tried by pressure testing machine following 7 days, 14 days or 28 days relieving. The example is set midway on the base plate of machine and the heap must be apply progressively at the pace of $140 \mathrm{~kg} / \mathrm{cm} 2$ every moment till the example comes up short. Burden at the disappointment isolated by region of test invigorates the Compressive of cement. The example to expanded burden separates and no more prominent burden more noteworthy burden can be consistent. The greatest burden applied to example will at that point be recorded and any strange worth noted at the hour of disappointment brought out in the report. The 3D shape Compressive quality, at that point

$f_{c}=\frac{P}{A} N / m^{2}$

Where $\mathrm{P}$ are the extreme load in $\mathrm{N}$,

A will be cross sectional area of block in $\mathrm{mm}^{2}$.

\section{Split Tensile Strength of Concrete}

To evaluate the spilt tensile strength of cylinder using following relation

$f_{t}=\frac{2 P}{\pi D L}$

Where,

$f_{t}$ is split tensile strength,

\section{$\mathrm{P}$ is Extreme load in $\mathrm{KN}$}

$\mathrm{L}$ is length of the cylinder in $\mathrm{mm}$

$\mathrm{D}$ is diameter of the cylinder in $\mathrm{mm}$

\section{Flexure Strength Test}

The load will be expanded until the example comes up short, and the most extreme burden applied to the example during the test will be recorded.

Where, Modulus of rupture $\mathrm{f}=\mathrm{PL} / \mathrm{BD} 2$

$\mathrm{P}$ is the load in $\mathrm{KN}$.

$\mathrm{L}, \mathrm{B}$ is the length and breadth in $\mathrm{mm}$.

$\mathrm{D}$ is the depth in $\mathrm{mm}$.

$F$ is the flexure strength in $\mathrm{N} / \mathrm{mm} 2$ 
International Journal of Research in Advent Technology, Vol.8, No.5, May 2020

E-ISSN: 2321-9637

Available online at www.ijrat.org

IV. EXPERIMENTAL RESULT

The results completed in the present investigation are reported in the form of Tables and Graphs for various percentage of recycled aggregate as a replacement to coarse aggregate. The following are the percentages replacement of cement i.e. $20 \%, 40 \%, 60 \%, 80 \%, 100 \%$.

\section{SLUMP TEST}

Table 5: Slump Test Result

\begin{tabular}{|c|c|c|}
\hline Sr. No. & Type of Concrete Mix & Slump in Mm \\
\hline 1 & A 0 & 25.5 \\
\hline 2 & A1 & 22 \\
\hline 3 & A2 & 24 \\
\hline 4 & A3 & 26 \\
\hline 5 & A 4 & 25 \\
\hline 6 & A5 & 23 \\
\hline
\end{tabular}

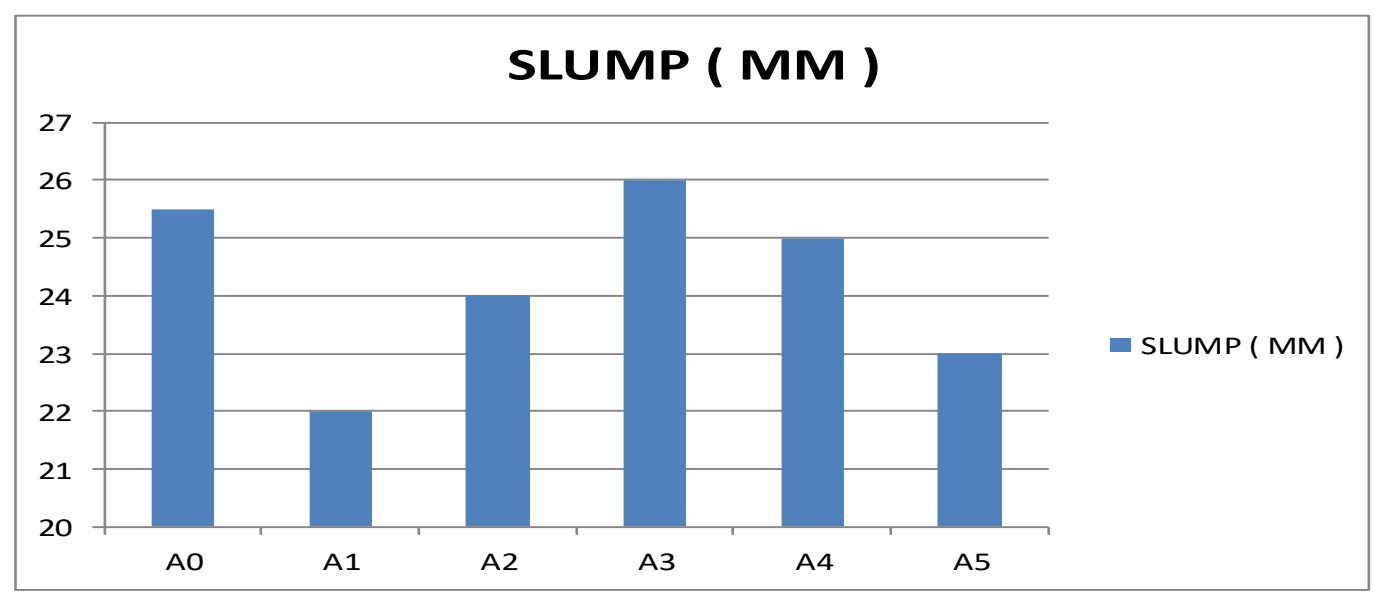

Graph 1: Slump(mm)

Compressive Strength Results

Table 6: Compressive Strength Test Result

\begin{tabular}{|c|c|c|c|c|c|}
\hline MIX ID & $\begin{array}{c}\text { \% RECYCLED } \\
\text { AGGREGATE }\end{array}$ & $\begin{array}{c}\text { TENSILE } \\
\text { STRENGTH } \\
\text { AT AGE OF 7 } \\
\text { DAYS, MPa }\end{array}$ & $\begin{array}{c}\text { TENSILE } \\
\text { STRENGTH } \\
\text { AT AGE OF 14 } \\
\text { DAYS, MPa }\end{array}$ & $\begin{array}{c}\text { TENSILE } \\
\text { STRENGTH } \\
\text { AT AGE OF 28 } \\
\text { DAYS, MPa }\end{array}$ & $\begin{array}{c}\text { TENSILE AGE OF 56 } \\
\text { AT DAYG, MPa } \\
\text { DAYS, }\end{array}$ \\
\hline A0 & 0 & 19.2 & 28.4 & 30.2 & 31.8 \\
\hline A1 & 20 & 25.2 & 29.2 & 30.4 & 32.4 \\
\hline A2 & 40 & 19.8 & 26.4 & 29.5 & 33 \\
\hline A3 & 60 & 29.4 & 30.2 & 32.4 & 36.5 \\
\hline A4 & 80 & 26.5 & 28.8 & 30.8 & 32.5 \\
\hline A5 & 100 & 27.5 & 28.5 & 31.2 & 30.8 \\
\hline
\end{tabular}

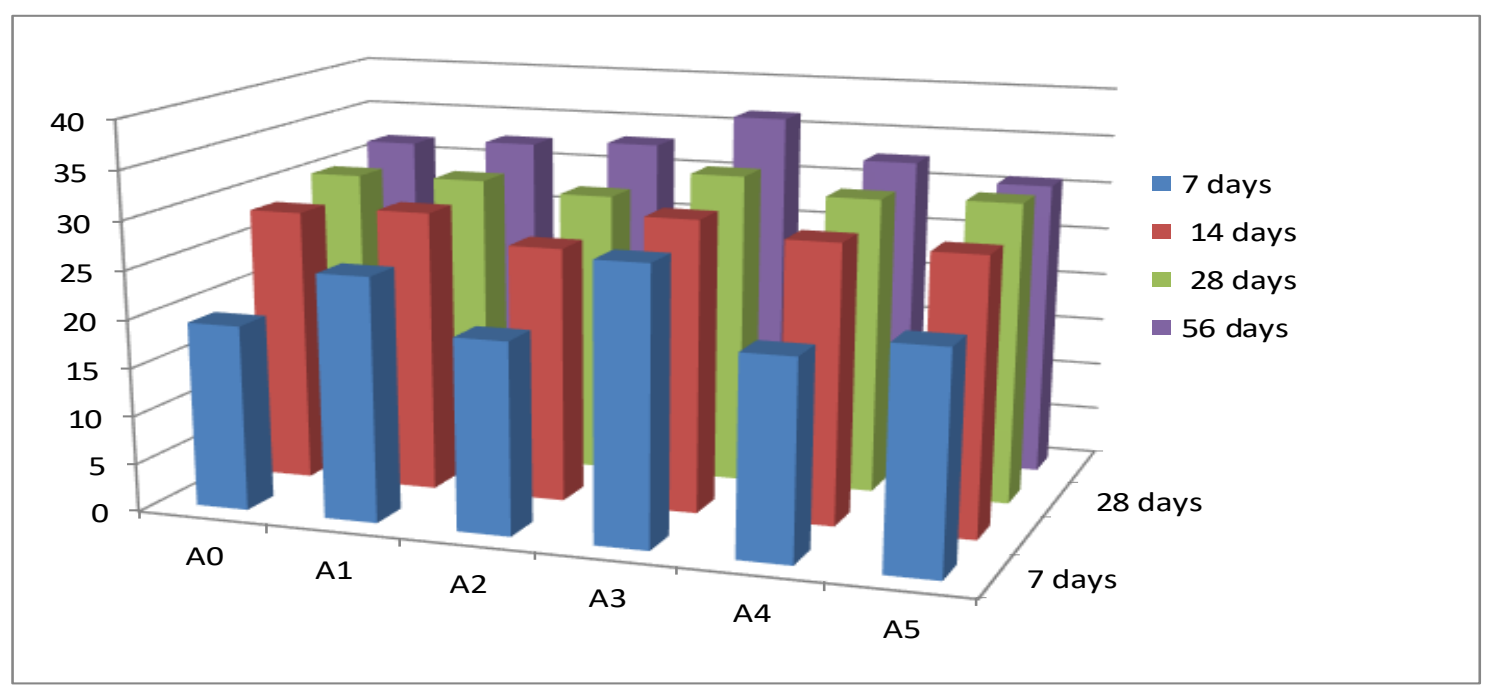

Graph 2: Compressive Strength Test Result Graph 
International Journal of Research in Advent Technology, Vol.8, No.5, May 2020

E-ISSN: 2321-9637

Available online at www.ijrat.org

Split Tensile Strength Test Results

Table 7: Split Tensile Strength Test Result

\begin{tabular}{|c|c|c|c|c|c|}
\hline MIX ID & $\begin{array}{c}\text { \% RECYCLED } \\
\text { AGGREGATE }\end{array}$ & $\begin{array}{c}\text { TENSILE } \\
\text { STRENGTH } \\
\text { AT AGE OF 7 } \\
\text { DAYS, MPa }\end{array}$ & $\begin{array}{c}\text { TENSILE } \\
\text { STRENGTH } \\
\text { AT AGE OF 14 } \\
\text { DAYS, MPa }\end{array}$ & $\begin{array}{c}\text { TENSILE } \\
\text { STRENGTH } \\
\text { AT AGE OF 28 } \\
\text { DAYS, MPa }\end{array}$ & $\begin{array}{c}\text { TENSILE } \\
\text { ATRENGTH AGE OF 56 } \\
\text { DAYS, MPa }\end{array}$ \\
\hline A0 & 0 & 19.2 & 28.4 & 30.2 & 31.8 \\
\hline A1 & 20 & 25.2 & 29.2 & 30.4 & 32.4 \\
\hline A2 & 40 & 19.8 & 26.4 & 29.5 & 33 \\
\hline A3 & 60 & 29.4 & 30.2 & 32.4 & 36.5 \\
\hline A4 & $\mathbf{8 0}$ & 26.5 & 28.8 & 30.8 & 32.5 \\
\hline A5 & 100 & 27.5 & 28.5 & 31.2 & 30.8 \\
\hline
\end{tabular}

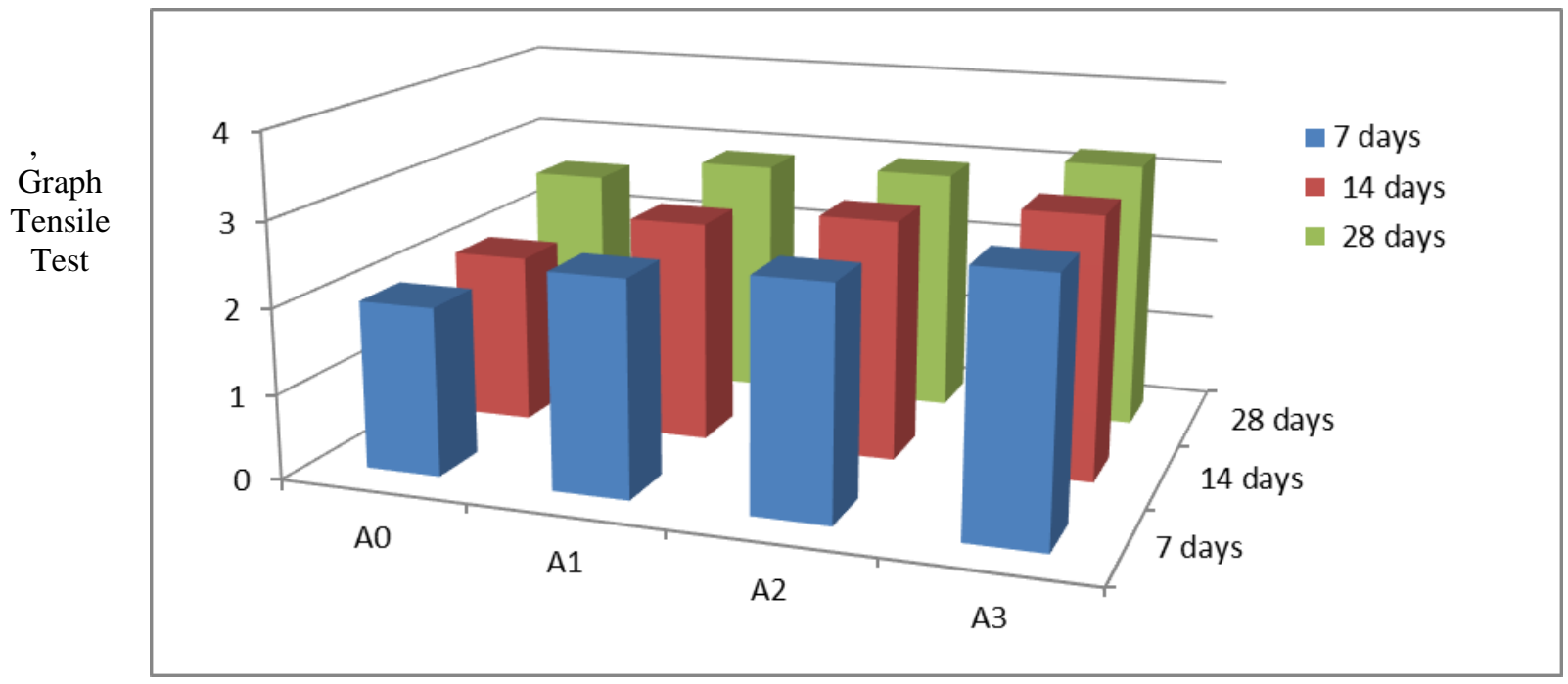

3: Split

Strength

Result

Flexural Strength Test Results

Table 8: Flexural Strength Test Result

\begin{tabular}{|c|c|c|c|c|c|}
\hline MIX ID & $\begin{array}{c}\text { \% RECYCLED } \\
\text { AGGREGATE }\end{array}$ & $\begin{array}{c}\text { FLEXURAL } \\
\text { STRENGTH } \\
\text { AT AGE OF 7 } \\
\text { DAYS, MPa }\end{array}$ & $\begin{array}{c}\text { FLEXURAL } \\
\text { STRENGTH } \\
\text { AT AGE OF 14 } \\
\text { DAYS, MPa }\end{array}$ & $\begin{array}{c}\text { FLEXURAL } \\
\text { STRENGTH } \\
\text { AT AGE OF 28 } \\
\text { DAYS, MPa }\end{array}$ & $\begin{array}{c}\text { FLEXURAL } \\
\text { STRENGTH } \\
\text { AGE OF 56 } \\
\text { DAYS, MPa }\end{array}$ \\
\hline A0 & 0 & 9.55 & 9.62 & 9.8 & 10.15 \\
\hline A1 & 20 & 9.432 & 9.85 & 9.92 & 10.5 \\
\hline A2 & 40 & 9.76 & 9.97 & 10.2 & 10.8 \\
\hline A3 & 60 & 9.8 & 10.4 & 10.4 & 11.2 \\
\hline A4 & 80 & 9.75 & 9.82 & 10.12 & 10.62 \\
\hline A5 & 100 & 9.52 & 9.6 & 9.8 & 10.35 \\
\hline
\end{tabular}


International Journal of Research in Advent Technology, Vol.8, No.5, May 2020

E-ISSN: 2321-9637

Available online at www.ijrat.org

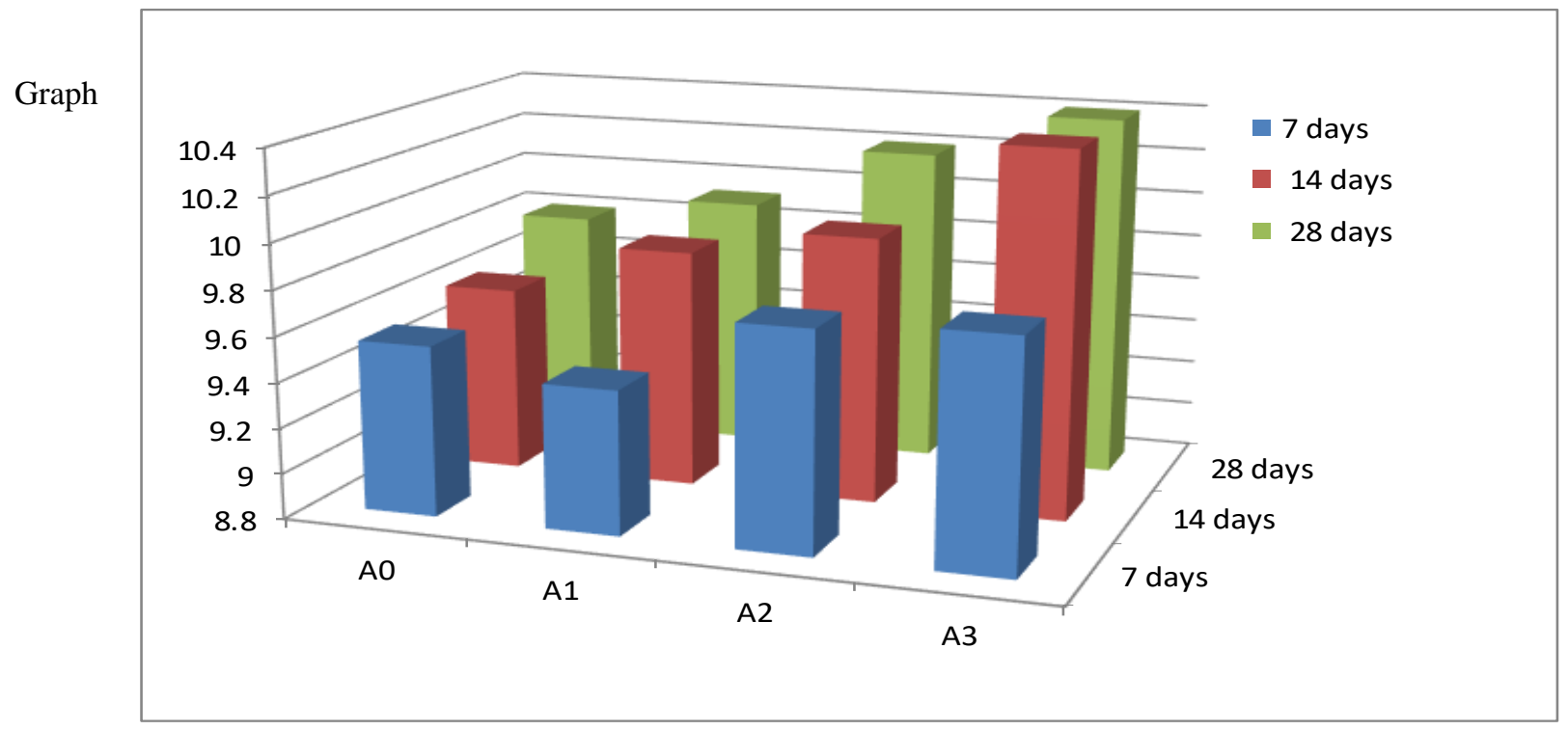

Flexural Strength test results

\section{TEST RESULTS}

Table 9: Test Results of Compressive Strength, Split Tensile Strength \& Flexural Strength Test Result For 7, 14, 28 \& 56 Days

\begin{tabular}{|c|c|c|c|c|c|c|c|}
\hline \multicolumn{2}{|c|}{ NAME OF THE TEST } & A0 & A1 & A2 & A3 & A4 & A5 \\
\hline \multirow{4}{*}{$\begin{array}{c}\text { COMPRESIVE } \\
\text { STRENGTH IN MPa }\end{array}$} & 7 DAYS & 19.2 & 25.2 & 19.8 & 29.4 & 26.5 & 27.5 \\
\hline & 14 DAYS & 28.4 & 29.2 & 26.4 & 30.2 & 28.8 & 28.5 \\
\hline & 28 DAYS & 30.2 & 30.4 & 29.5 & 32.4 & 30.8 & 31.2 \\
\hline & 56 DAYS & 31.8 & 32.4 & 33 & 36.5 & 32.5 & 30.8 \\
\hline \multirow{4}{*}{$\begin{array}{c}\text { SPLIT TENSILE } \\
\text { STRENGTH IN MPa }\end{array}$} & 7 DAYS & 19.2 & 25.2 & 19.8 & 29.4 & 26.5 & 27.5 \\
\hline & 14 DAYS & 28.4 & 29.2 & 26.4 & 30.2 & 28.8 & 28.5 \\
\hline & 28 DAYS & 30.2 & 30.4 & 29.5 & 32.4 & 30.8 & 31.2 \\
\hline & 56 DAYS & 31.8 & 32.4 & 33 & 36.5 & 32.5 & 30.8 \\
\hline \multirow{4}{*}{$\begin{array}{c}\text { FLEXURE STRENGTH } \\
\text { IN MPa }\end{array}$} & 7 DAYS & 9.55 & 9.432 & 9.76 & 9.8 & 9.75 & 9.52 \\
\hline & 14 DAYS & 9.62 & 9.85 & 9.97 & 10.4 & 9.82 & 9.6 \\
\hline & 28 DAYS & 9.8 & 9.92 & 10.2 & 10.4 & 10.12 & 9.8 \\
\hline & 56 DAYS & 10.15 & 10.5 & 10.8 & 11.2 & 10.62 & 10.35 \\
\hline
\end{tabular}




\section{ConClusion}

Solid reusing will get one of the most significant components for development manageability. Concrete in which folios, added substances and totally made of cement and materials of cement and these materials are used as unrefined materials of cement in the wake of hardening. Solid which contains waste items are aggregate are known as 'Green' concrete. This paper investigates the plausibility of waste aggregate in construction to make green cement. Based on limited experimental investigation concerning the strength tests i.e. compression, split tensile and flexural strength the following observations are regarding the resistance of replacement done with Recycled Coarsed Aggregate to Natural Coarsed Aggregate and Recycled Fine Aggregate to Natural Fine Aggregate in M25 concrete.

\section{CONFLICT OF INTEREST}

On behalf of author states that there is no conflict of interest.

\section{REFERENCES}

[1] Ferrari, Surico, Brocchi, Banfi, Maltese, Squinzi, "Method for recycling concrete" European Journal, June-2012..

[2] Nikita Patel, Dr. Piyush Patel, "Use of Demolished Concrete Materials in Concrete and Comparative Study of its Mechanical Properties: NDT Comparison", International Journal of Innovative Research in Science, Engineering and Technology, Vol. 5, Issue 4, April 2016.

[3] Preeti Saini, Deepakar Kr. Ashish "A Review on Recycled Concrete Aggregates "SSRG International Journal of Civil Engineering (SSRGIJCE), pp: 71-75, April-2015.

[4] P. Saravanakumar and G. Dhinakaran"Mechanical and Durability Properties of Slag Based Recycled Aggregate Concrete" IJST, Vol-39, pp271-282, Feb 2015.

[5] Jitender Sharma, Sandeep Singla, "Study of Recycled Concrete Aggregates", International Journal of Engineering Trends and Technology (IJETT),Vol-3, Issue No-7, pp- 123-125,July-2014

[6] Manish Kumar Singh, Dilip Kumar "Physical Properties of Construction \& Demolished Waste Concrete", IJSRD - International Journal for Scientific Research \& Development,Vol-2,Issue No-8,pp-122-123, 2014.

[7] Prof. Abdul Ghaffar, Imran Siddiqui, Swapnil Alone, Sachin Meshram, Sneha Telang, "Review Paper On Use Of Demolished Concrete Materials In Concrete", International Journal of Advance Engineering and Research Development, Volume 6, Issue 03, March -2019.

[8] Arpiti Kumari Koshta, Ashutoshi Verma, Rupali Goud, "Utilization Of Concrete Demolished Waste In Cement Concrete", International Research Journal of Engineering and Technology (IRJET), Volume: 07 Issue: 04, Apr 2020.

[9] Srivastava, Vikas \& Monish, Mohd \& Ranjan, Raushan \& Mehta, Pradeep. (2015). Demolition Waste in Concrete.

[10] Al-Bared, Mohammed \& Ayub, Azimah \& Mohd yunus, Nor Zurairahetty \& Harahap, Indra \& Marto, Aminaton. (2018). Application of demolished concrete material (DCM) in civil engineering structures - A review. International Journal of Civil Engineering and Technology. 9. 2345-2352.

[11] Anagha Kalpavalli, Dr. S. M. Naik, "Use of Demolished Concrete Wastes As Coarse Aggregates in High Strength Concrete Production", International Journal of Engineering Research \& Technology (IJERT), Vol. 4 Issue 07, July-2015.

\section{AUTHORS PROFILE}

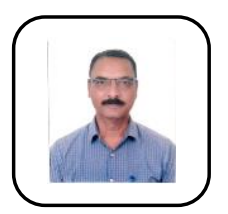

Prof. Manish D. Deshmukh completed his Master degree in Environmental Engineering from Sant Gadge Baba Amravati University, Amravati. Currently working as Assistant Professor at P. R. Pote College of Engineering, Amravati. He has presented papers at various National and international conferences both international journals. 